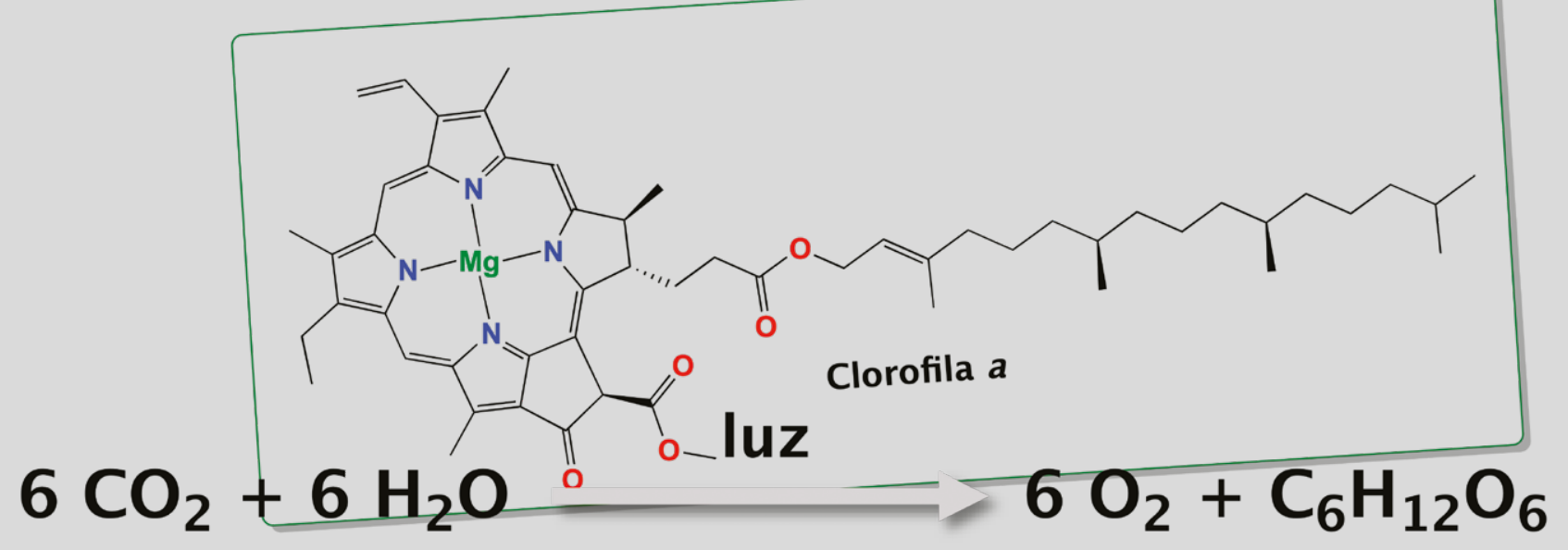

\title{
A Cor Verde das Folhas das Plantas isaranion
}

A cor verde de plantas, arbustos e árvores é associada com o bem-estar ambiental e com uma Natureza de "boa saúde". Faz sentido, já que nas partes verdes das plantas ocorre a fotossíntese que é essencial para que a vida exista na Terra.

A cor verde que tanto admiramos na natureza é devida à presença das clorofilas. As clorofilas são uma família de compostos químicos que são capazes de absorver a luz nas regiões do azul e vermelho do espectro eletromagnético, não absorvendo a luz verde. Portanto, é a radiação correspondente à cor verde que atinge os nossos olhos, sendo a cor que vemos ao olharmos para uma folha. As clorofilas são os pigmentos naturais mais abundantes nas plantas, estando presentes nos cloroplastos das folhas e em outros tecidos vegetais.

Todas as células fotossintetizantes, isto é, todas as células capazes de realizar a reação química designada por fotossíntese, exceto as bacterianas, contêm dois tipos de clorofila, em que uma delas é sempre a clorofila $a$. A energia obtida através da absorção de luz permite a transformação de dióxido de carbono e água em glicose e oxigénio, reação química que expressa o processo da fotossíntese. Assim, a fotossíntese é fonte de oxigénio, essencial a muitos dos seres vivos do planeta, e é também

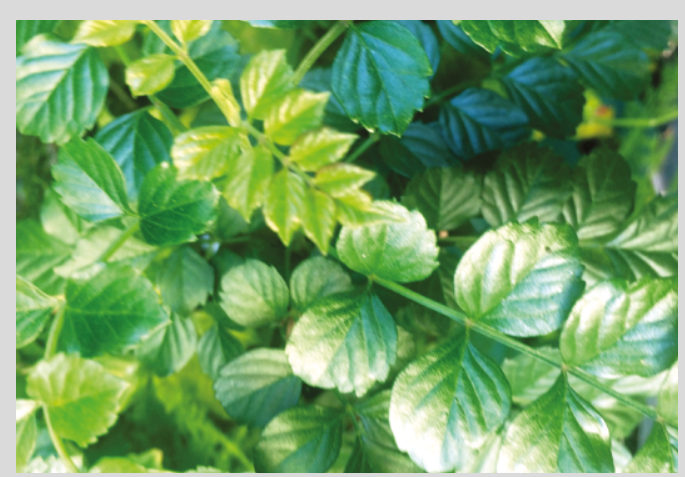

responsável pela produção de energia. A reação química que acontece nos organismos fotossintetizantes é a base das cadeias alimentares tanto terrestres quanto aquáticas, e as clorofilas são os compostos químicos na sua base.

\section{Saiba mais em:}

"Pigmentos fotossintetizantes" em Só Biologia. Virtuous Tecnologia da Informação, 2008-2020. Disponivel em sobiologia.com.br/conteudos/bioquimica/ bioquimica13 (acedido em 29/10/2021).

Infoescola, Navegando e aprendendo. Disponível em infoescola.com/plantas/ clorofila (acedido em 29/10/2021).

J. M. Berg, J. L. Tymoczko, L. Stryer, Light Absorption by Chlorophyll Induces Electron Transfer em Biochemistry $5^{\text {th }}$ Edition, W H Freeman, New York, 2002. Disponível em ncbi.nlm.nih.gov/books/NBK22535 (acedido em 29/10/2021). 